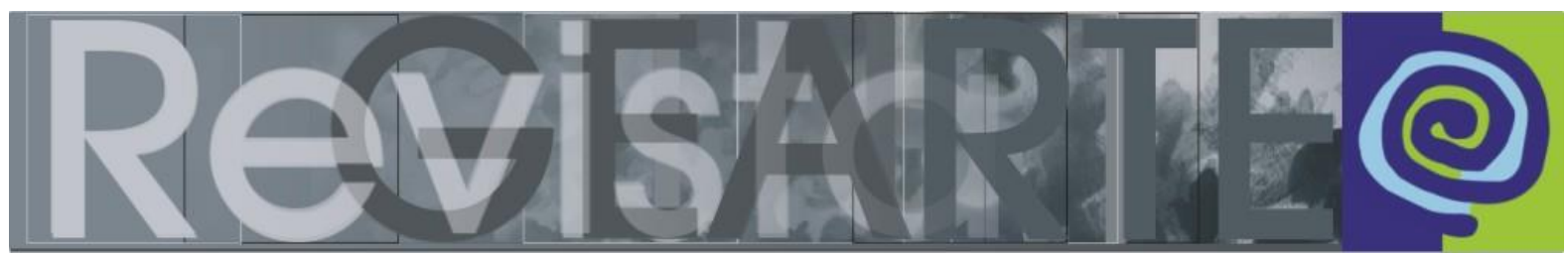

ISSN 2357-9854 | e-ISSN 2596-3198 (online)

\title{
Arte/Educação e feminismo no imaginário pernambucano como resistência política e formação identitária das mulheres
}

\author{
Maria das Vitórias Negreiros do Amaral \\ (Universidade Federal de Pernambuco — UFPE, Recife/PE, Brasil)
}

\begin{abstract}
RESUMO - Arte/Educação e feminismo no imaginário pernambucano como resistência política e formação identitária das mulheres - Na Graduação em Artes Visuais da UFPE, com o objetivo de formação de professoras e professores, nós, professoras do curso, ministramos disciplinas para que esses/essas estudantes vão aos espaços educativos sendo esses formais: as escolas; ou não-formais: museus, galerias, ONGs, hospitais, entre outros, com a consciência de que somos um grupo cultural colonizado, especificamente em relação às artes visuais. $E$ precisamos estudar, pesquisar e compreender um ensino/aprendizagem contemporâneo, democrático e inclusivo. Para isso, fundamentadas em teorias feministas, fazemos escolhas de trabalhos artísticos em que contemplem as mulheres, indígenas, pretas, pessoas com deficiências e de grupos LGBT. Discutir as teorias de autoras mulheres que trazem à luz os trabalhos artísticos dessas, que por muito tempo foram invisibilizadas por historiadores homens, também é outro ponto fundamental nessa perspectiva de Arte/Educação. Com a arte, discutimos questões como a misoginia, homofobia e preconceitos outros que excluem as pessoas da sociedade e da história da arte. Levando essa temática para a sala de aula, fomentamos um movimento circular, no qual as artistas e trabalhos de arte são estudados, levando as/os professores/as em formação a produzirem/pesquisarem arte; a partir dessa produção/pesquisa/reflexão em arte proporcionar à a sociedade em seus estágios obrigatórios e não obrigatórios, em pesquisas de PIBIC, PIBITI, PIBID, o objetivo de transformar e buscar uma sociedade mais justa, democrática, inclusiva e decolonializada. Para exemplificar essa ciclicidade, trago três estudantes e pesquisadoras do PIBIC apresentando suas produções artísticas.
\end{abstract}

PALAVRAS-CHAVE

Feminismo. Arte/Educação. Imaginário. Artes Visuais. (de)Colonialismo.

RESUMEN - Arte / Educación y feminismo en el imaginario pernambucano como resistencia política y formación identitaria de las mujeres - En la Graduación en Artes Visuales de la UFPE, con el objetivo de formación de profesoras y profesores, nosotros, profesoras del curso, ministramos disciplinas para que esos / as estudiantes van a los espacios educativos, sean estos formales: las escuelas; o no formales: museos, galerías, ONGs, hospitales, entre otros, con la conciencia de que somos un grupo cultural colonizado, específicamente en relación a las artes visuales. Y necesitamos estudiar, investigar y comprender una enseñanza/aprendizaje contemporánea, democrática e inclusiva. Para ello, fundamentadas en teorías feministas, hacemos elecciones de trabajos artísticos en que contemplen a las mujeres, indígenas, negros, personas con discapacidades y grupos LGBT. Discutir las teorías de autoras mujeres que traen a la luz los trabajos artísticos de esas, que por mucho tiempo fueron invisibilizadas por historiadores hombres, también otro punto fundamental en esta perspectiva. Con el arte, discutimos cuestiones como la misoginia, homofobia y prejuicios otros que excluyen a las personas de la sociedad y de la historia del arte. Al llevar esta temática al aula, fomentamos un movimiento circular, en el que se estudian artistas y trabajos de arte, llevando a los profesores / as en formación a producir / investigar arte; a partir de esa producción / investigación / reflexión en arte proporcionar a la sociedad en sus etapas obligatorias y no obligatorias, en investigaciones de PIBIC, PIBITI, PIBID, el objetivo de transformar y buscar una sociedad más justa, democrática, inclusiva y decolonializada. Para ejemplificar esa ciclicidad, yo traigo tres estudiantes e investigadores del PIBIC presentando sus producciones artísticas.

\section{PALABRAS CLAVE}

Feminismo. Arte / Educación. Imaginario. Artes Visuales. (de)Colonialismo.

AMARAL, Maria das Vitórias Negreiros do. Arte/Educação e feminismo no imaginário 


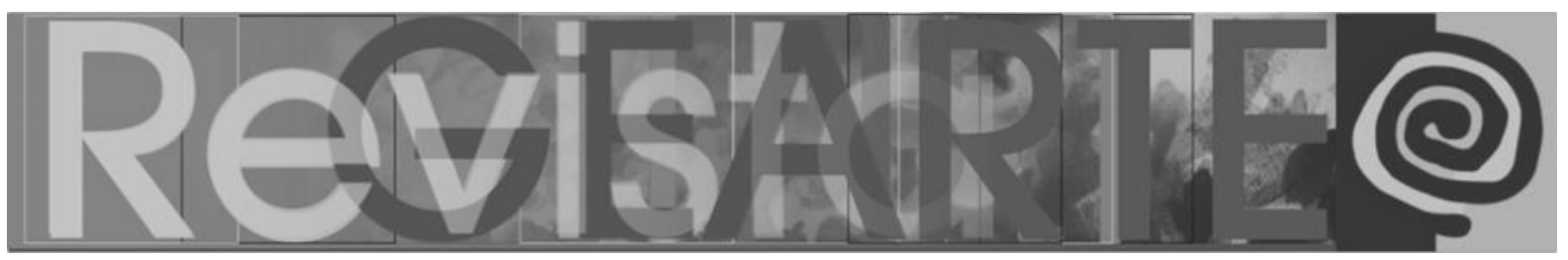

Sempre que vou a um restaurante nigeriano, o garçon cumprimenta o homem e me ignora. Os garçons são produto de uma sociedade onde se aprende que os homens são mais importantes do que as mulheres, e sei que eles não fazem por mal - mas há um abismo entre entender uma coisa racionalmente e entender a mesma coisa emocionalmente (ADICHIE, 2015, p. 13).

Será que no Brasil é diferente? Quando o garçom traz a conta para ser paga, se estiverem à mesa uma mulher e um homem, ele entrega a quem? A quem ele se dirige? Quando Chimamanda, autora da epígrafe que abre este trabalho, fala, de maneira simples, sobre a necessidade de nos tornarmos feministas, ela não deseja reverberar uma superioridade das mulheres com relação aos homens, mas simplesmente chamar a atenção para que elas precisam e devem ter visibilidade, de modo que possam ser tiradas do apagamento a que são submetidas nas relações sociais cotidianas. Seu discurso se pauta no fato de que a sociedade é formada por um grupo de pessoas diferentes e que todas devem ser respeitadas, terem vez e voz.

Vivemos em uma sociedade com comportamentos padronizados, normatizados, cujos espaços são considerados dos homens, mesmo porque quem dita as regras que nesses espaços circulam e neles se mantém são os homens. Para exemplificar esses comportamentos, vou contar um fato que aconteceu na universidade - sabendo que histórias como essa são, infelizmente, comuns, tanto comigo como com outras mulheres!

Certa vez, então, um professor, que se dirigia a mim como "colega" (como se estivéssemos em pé de igualdade), se surpreendeu quando eu disse que era casada há muitos anos, e ele me disse: "Mas você é tão risonha, não pensei que fosse casada!". Não entendi. Ou melhor, entendi, mas fiquei assombrada, pensando em como um professor universitário, nos dias de hoje, em pleno século 21, poderia ter tal pensamento, evidentemente preconceituoso. Mulheres casadas não riem? Para ele e para muitas outras pessoas, é óbvio que não. Eles acreditam que quando as mulheres casam se tornam "recatadas e do lar" e devem perder a sua identidade de mulher, afinal assumem o nome do marido, seus amigos e sua vida. A mulher deixa de ser ela para ser "dele". Na institucionalização do casamento, formal ou não formal, ocorre 


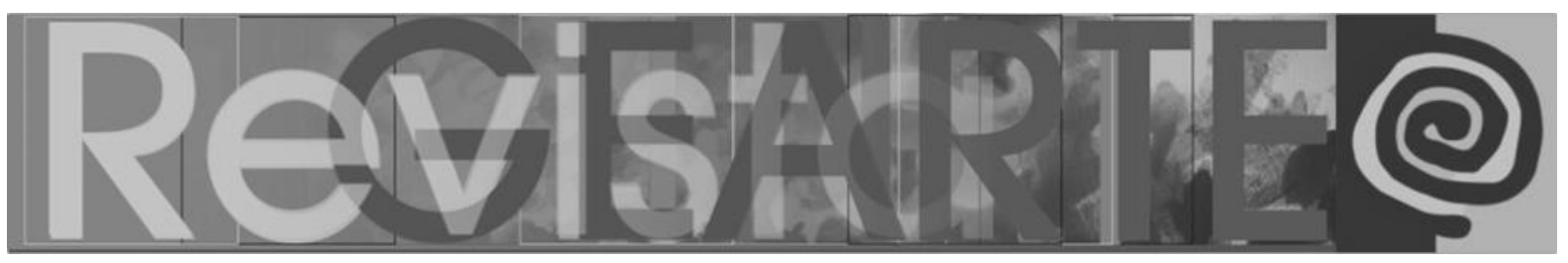

uma nefasta apropriação indevida e bastante desigual em uma relação de poder de gêneros, que se manifesta de maneiras diversas. O professor nem sequer questionou se eu seria casada com um homem ou com uma mulher, na certa teria certeza que seria com um homem, porque em um pensamento da verdade absoluta e em uma sociedade homofóbica, só poderia ser um homem

Muitas mudanças estão ocorrendo na sociedade, mas não o suficiente para que esse tipo de comentário não aconteça mais. Ideias acerca da discussão desses temas e mesmo a organização deste texto que apresento são o fundamento para a elaboração e orientação de trabalhos que coordeno e oriento na Universidade, mas também servem como fonte de crença e inspiração para que eu possa conseguir avançar cada vez mais nas temáticas, incluindo-as nas atividades que proponho aos/às estudantes do curso em que leciono. Assim, ainda com relação ao comentário, é interessante nos reportarmos à fala de Gilbert Durand (1997), antropólogo que criou a Teoria do Imaginário, para quem seria necessário passar três gerações para as mudanças culturais realmente ocorrerem e se tornarem práticas efetivas no cotidiano. Se, do ponto de vista histórico, considerarmos todas as lutas travadas pelas mulheres, já teríamos passado por três gerações; porém, a batalha, real ou simbólica, pela igualdade ou, como querem alguns, pelo poder, vem acompanhada de retrocessos. $\mathrm{E}$ para vermos uma mulher rir, gargalhar, ser e estar como quiser, independentemente de estar sozinha, acompanhada ou com quem queira estar, ainda falta a passagem de algumas outras gerações. Além dessa passagem do tempo, é evidente que devemos trazer ao entendimento o fato de que "El análisis comienza en la noción de heterogeneidad, la qual implica que no todas las mujeyes somos iguales ni ocupamos los mismos roles en las relaciones sociales: cubrimos identidades diversas, que pueden ser cambiantes, múltiples y contradictorias" (LARRALDE, 2018, p. 64), o que significa que as mulheres não são iguais e, por conseguinte, as identidades são muitas. É contra essa heterogeneidade que se porta o sistema, que, ao desconsiderar a igualdade de gêneros, como estamos discutindo, tenta apagar dados sociais e culturais importantes que dizem respeito à própria formação dos diversos grupos, como o próprio movimento feminista: "Há muitos feminismos. O que importa é lutar 


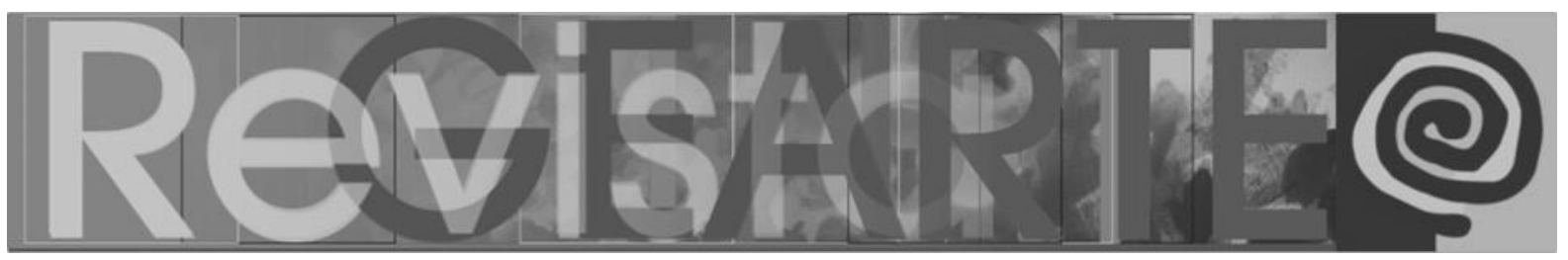

contra a violência social, institucional e física que as mulheres sofrem, e reescrever a História da Arte, que eliminou metade dos seres humanos deste planeta, a metade feminina" (BARBOSA in ZACARRA, 2017, p. 14).

As concepções de casal, de sexualidade e de família vêm sendo modificadas ao longo das últimas décadas. Acredito que desde sempre as lutas de gênero acontecem nas sociedades ocidentais e ocidentalizadas, que são as que estamos tratando aqui. As mulheres lutam por ocupar seus espaços, em princípio individualmente, no âmbito de sua vida privada; depois elas se organizaram para terem voz coletivamente, como aconteceu, por exemplo, com a luta pelo voto empreendida pelas sufragistas e, posteriormente, já na década de 1960, a organização de fato dos movimentos feministas possibilitou de modo contundente uma mudança de visão de mundo. Nomeados ou não, midiatizados ou não, os movimentos feministas acontecem de maneiras diversas em todas as partes do mundo, cada um em um momento distinto. Em nosso recorte, consideramos que o movimento feminista se iniciou nos anos 1960 e teve como meta, naquela época, o combate ao ideal socialmente propagado que "dessexualizava a mulher e que valorizava a associação romântica do feminino" (RAGO, 2004, p. 283).

As mulheres que compunham o movimento se opunham fortemente à imagem da mulher que não seria dona do próprio corpo, imagem essa amplamente divulgada e mesmo assumida por muitas mulheres. A manifestação desse ideal pode ser verificada nas imagens da arte que apresentam a mulher como objeto do desejo do homem, corroborando, inclusive, as próprias publicidades e o próprio cinema, que, desde seu início, décadas antes, tratavam da mulher de maneira também objetificada e com fins puramente comerciais/econômicos. Com o intuito de combater essa ideologia, "(...) o feminismo também abriu mão do corpo, da beleza, da estética e da moda, considerados reificadores, apropriando-se paradoxalmente do modo masculino de existência que questionava e, ao mesmo tempo, desconstruía" (Ibidem). Ainda de acordo com Rago, essas mulheres foram "outrora associada[s] às figuras negativas da feiura e da velhice, ou taxadas de 'sapatão' e 'mal-amadas”' (RAGO, 2004, p. 283). 


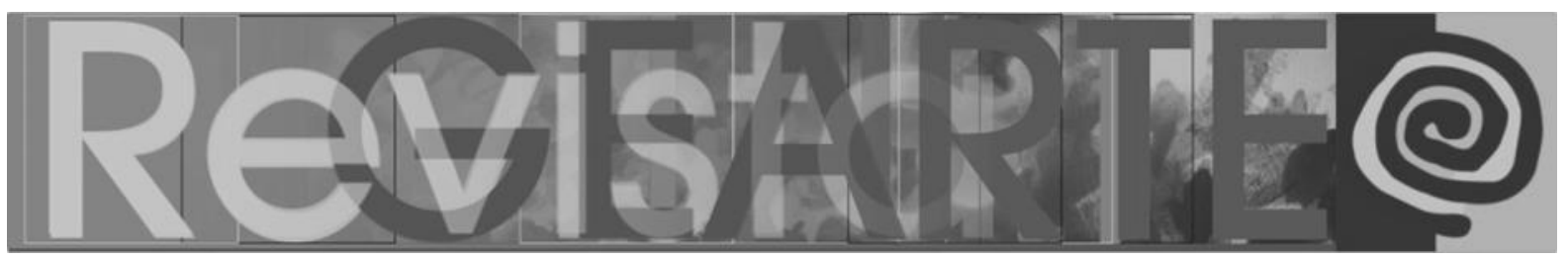

Aqui faço um parêntese para dizer que ao discutir sobre o feminismo e sobre a mulher, seja essa cis, trans, ou quem mais se considerar mulher, não estou defendendo as oposições binárias, mas pretendo tratar de questões que, apesar de muitas lutas, ainda não foram resolvidas e sobre as quais ainda temos muito que discutir, como, por exemplo, a invisibilidade da mulher na arte, no cotidiano profissional e pessoal, no público e no privado, enfim, em todas as esferas da vida; a constante violência contra a mulher, seja ela física ou simbólica, e, além disso tudo, o próprio caleidoscópio que orienta a formação e a manutenção das identidades de mulher. Desse modo, com essa importante pauta formada pelos temas elencados e relacionada à área da Educação, acreditamos que os componentes que integram as práticas de ensino/aprendizagem da arte podem se tornar não apenas um dos vieses que faz o sujeito a se descobrir como cidadã ou cidadão, mas principalmente como um mecanismo que instaura uma possibilidade de fazer emergir na sala de aula (na escola, na comunidade, e assim por diante) uma resistência política e de empoderamento da mulher.

Com as mudanças culturais desencadeadas a partir das realizações - nem sempre pacíficas - que envolvem a atuação dos movimentos feministas, e dentre elas podemos citar a literatura escrita por mulheres, sejam os romances, as biografias e as autobiografias; a história linear abre espaço para coexistir com narrativas cíclicas que até então, embora existissem de fato, não tinham espaço de discussão e de divulgação. Isso, a nosso ver, é tão importante que a própria Academia vem ganhando novos contornos na grandiosa tarefa que the cabe, principalmente no sentido de repensar seus textos fechados em começo-meio-fim e, desse modo, caminha para reconsiderar o aspecto de unicidade que circunda a educação, que, por natureza, é plural e múltipla. O olhar feminino, que não é apenas da mulher, assim como o machismo não está apenas nos homens, vem transformando o paradigma científico, aportando a ele várias discussões consideradas até então simplesmente periféricas, modismos, dentre outros adjetivos desqualificadores. Segundo Rago, o feminismo: 


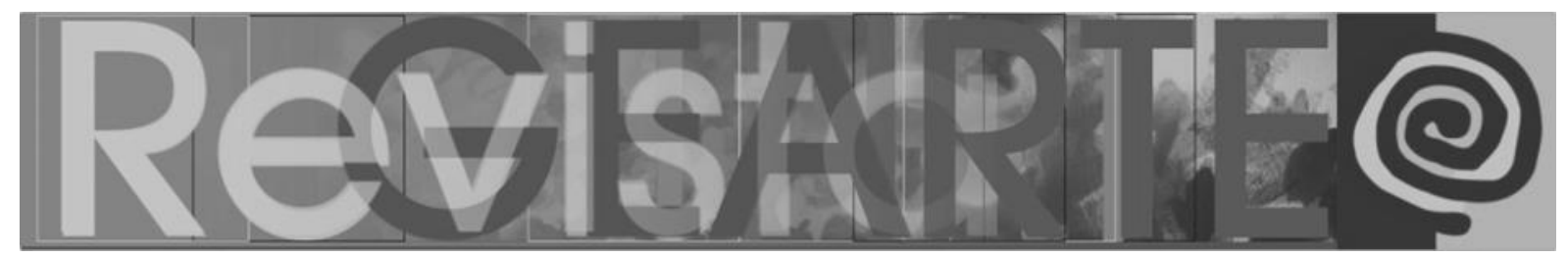

comportamentos, nas relações estabelecidas consigo e com os outros, nos sistemas de representações e no modo de pensar. Especialmente a partir da constituição de um novo olhar sobre si e sobre o outro - e, nesse sentido, penso num processo de feminização cultural em curso, o mundo tem se tornado mais feminino e feminista, libertário e solidário ou, em outras palavras, filógino, isto é, amigo das mulheres e do feminino, o que resulta decisivamente do aporte social e cultural das mulheres no mundo público (RAGO, 2004, p. 282).

Como defendemos/percebemos, tais atitudes podem ser observadas em algumas/alguns estudantes que ingressam no curso de Artes Visuais, como os/as da Universidade Federal de Pernambuco, que, ainda bem jovens, geralmente iniciam o curso com pouca e mesmo com nenhuma leitura sobre estudos de gênero. Essas/es estudantes apresentam-se, porém, como um público aberto à sua inserção em discussões aprofundadas a respeito de temas sociais amplamente difundidos, por exemplo, inclusive pelas redes sociais, meio pelo qual, conseguem estabelecer um maior engajamento a causas e a movimentos - não obstante a "superficialidade" que também caracteriza as relações nas redes, conforme veremos. Tais estudantes compõem a juventude que Margareth Rago denomina "pós-feminista", que tem um aspecto importante já incorporado em sua caracterização, pois ela tem uma relação mais libertária com o corpo, com o sexo, com o outro, com a natureza e com a vida; e isso facilita a essa juventude um mergulho - por vezes, bastante profundo - nas teorias feministas e nas relações de gênero e, no nosso caso, no ensino da arte. Esse ensino é, sabemos e defendemos, uma possibilidade de mudança social para o sujeito, mas também cultural e para a própria aprendizagem da arte.

E é justamente isso que tenho observado durante o tempo em que os/as estudantes passam no curso: uma mudança de postura, de aceitação de identidade, da construção e defesa de uma escrita mais libertária e a produção de trabalhos artísticos muito ligados a temas e a atitudes feministas. Consequentemente, está sendo criando um ciclo em que esses/essas estudantes estão levando tais temas e diversas abordagens sobre eles para suas práticas fora da universidade, seja nos seus estágios nas escolas, nos museus/galerias; na própria sala de aula, quando nela 




ingressam; no seu cotidiano e, portanto, nas relações sociais intersubjetivas que estabelecem com o outro, e mesmo com a arte.

\section{Contexto político da Arte/Educação brasileira}

O texto, até agora exposto, vem embasar o que realmente pretendo discutir, é um ciclo de ensino/aprendizagem em arte que se inicia na sociedade e no cotidiano dos/das estudantes, passa por um processo de teorização, experimentação e "artefincação" ou "artefluição". Artefincação quando a arte propicia esse mergulho nas próprias origens, reestruturação de corpos e as descobertas dos desejos; Artefluição, quando saímos do lugar comum, da normatividade para, por meio da arte, transpor as barreiras do preconceito, da misoginia e do racismo. Aprender/experimentar/produzir arte e os estudos sobre gêneros, raças e feminismos nos transformam e nos levam à sociedade com um olhar diferente para o mundo. Este ciclo é um eterno retorno, para citar Nietzche e Mircea Eliade.

Apresento, então, três pesquisas de PIBIC de Artes Visuais, da Universidade Federal Pernambuco (UFPE), com um diferente enfoque, com um olhar mais aguçado em relação às questões de gênero e raça, que tem o objetivo de elaborar uma pedagogia que relacione arte/educação e feminismo ${ }^{1}$. Por meio da orientação prevista no projeto, pretendíamos estabelecer novos diálogos entre a Educação e a Sociedade, compreendendo a dinâmica dos/as arte/educador/as como mediadores/as do conhecimento em arte, seja em escolas, seja em museus ou ongs, na educação formal ou não formal. Com efeito, seus resultados aliam-se ao encontro necessário de uma prática educacional que enfatize a subjetividade, própria do ensino de arte, com uma arte/educação inclusiva que abra espaços para a mulher artista e todos os elementos que fazem parte da produção artística marginal, como o artesanato, o

1 As pesquisadoras e suas pesquisas são: LIMA, Stefany Lopes de. Arte/Educação e Graffiti em Espaços não-formais: devolvendo a rua à juventude periférica (2017-2018); ARAÚJO, Allana Torquato de. Vozes Ocultas: uma reflexão sobre a estrutura curricular do curso de Licenciatura em Artes Visuais da UFPE (2018-2019); SILVA ,Thaysa Cordeiro. Estudos sobre o Panorama de Violência contra a Mulher no Recife e Práticas de Arte/Educação como RESISTÊNCIA (2018-2019). 


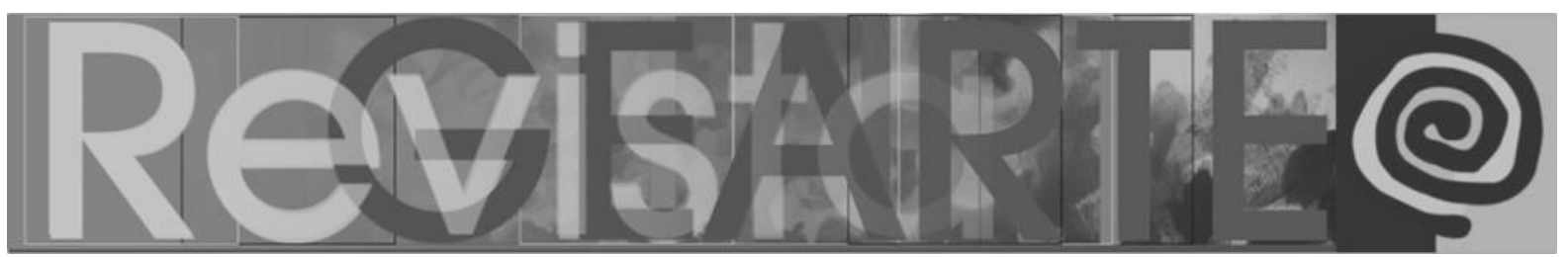

bordado, a cerâmica, o desenho, a gravura, as narrativas não lineares, com ênfase na afirmação de que o próprio cotidiano é fundamental para essas narrativas. Como exemplo dessas narrativas, podemos citar as narrativas feministas, que incluem todos aqueles/as artistas e trabalhos artísticos que estão fora da universidade. Como pano de fundo, intenta-se, ainda, no projeto, apresentar uma trajetória da inserção das mulheres no curso de Artes Visuais na UFPE, durante a graduação e/ou pósgraduação, e sua (re-)inserção na sociedade, mas então com novos aportes de conhecimento sobre a causa das mulheres, ampliando, desse modo, o olhar dos/as estudantes - e não simplesmente os/as colocando de cabeça para baixo, como tematiza ironicamente a charge da Mafalda a seguir (Figura 1):

Figura 1- Mafalda

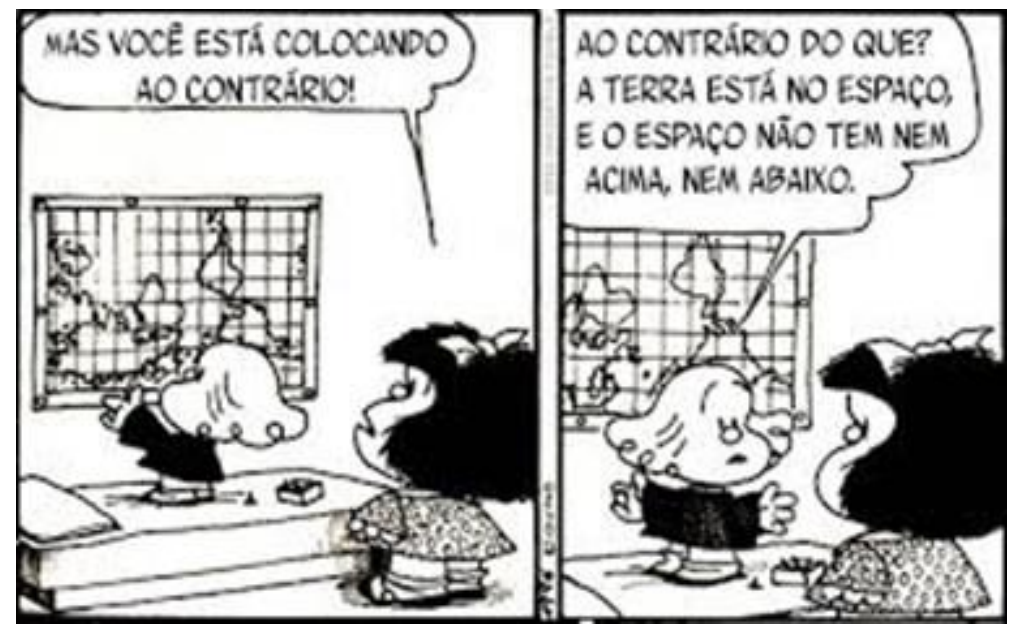

Fonte: http://formulageo.blogspot.com.br/2012/07/mafalda Acesso em: 06 jun. 2014.

Todas as escolhas que realizamos, inclusive na sala de aula, são efetuadas a partir de um ponto de vista, e este não é isento de política nem de ideologia. No nosso caso, trabalhamos com a desobediência estética e epistêmica, que, de acordo com Mignolo, "[esto] es, desobediência a las regras del haver artístico y a las regras de la búsqueda de sentido en el mismo universo en el que tanto las obras como la filosofia respondem a los mismos princípios. Las estéticas decoloniales buscan descolonizar los conceptos cómplices de arte y estética para liberar la subjetividad" (2012, p.10). Com isso, estamos considerando as produções artísticas locais e marginais e com certeza dando outra visibilidade e valor à arte e à estética. 


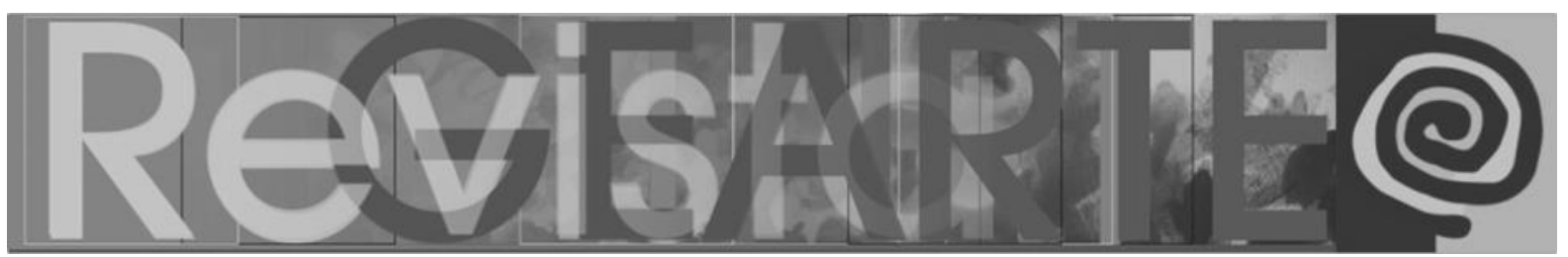

As mulheres, os/as indígenas, os/as negros/as, os/as pobres, as pessoas com deficiência, dentre outros agrupamentos, encontram-se focados, nessa forma de pensar, como o centro, saindo de sua alocação socialmente estigmatizada, isto é, do espaço de sentido construído como periférico ou como marginal. Tal reorganização, desse ponto de vista sobre a própria sociedade, que, ao longo dos séculos, foi pensada em função do capital como seu fator de existência, e cujos integrantes adeptos ao sistema repetem, como lema, a frase: "pior do que ser explorado é não ser"; tem como objetivo combater esse ideal nefasto, aliando-se ao trabalho de teóricos/as que refletem criticamente sobre as práticas de inserção de Arte e Política ou Decolonização ou Descolonização do conhecimento da Arte. Ou seja, nessa nova perspectiva, todos têm o interesse em comum de democratizar o conhecimento e ampliar os olhares, de modo a emancipar o ser humano que somos dos grilhões ideológicos que nos acorrentam à manutenção de um sistema que privilegia e mantém padrões já não condizentes com a realidade factual das sociedades.

A sociedade brasileira estava, a todo vapor, a caminho dessa democratização, a exemplo das políticas afirmativas de cotas para estudantes de escolas públicas, negros e negras; o início da demarcação de terras indígenas e quilombolas; o aporte de dignidade para pessoas que vivem em situações precárias; as expansões das universidades para os interiores do país, e muitas outras ações que tinham como fundamento basilar uma ideologia horizontalizada, com grupos de trabalhos funcionando mais do que uma estrutura vertical. Era um princípio de mudança! Mas, como dissemos anteriormente com relação às conquistas do feminismo, a cada avanço é possível que haja retrocessos, como é o caso aqui explanado: mesmo com os as melhorias sociais já observáveis e com as projeções das que ainda estavam por vir, aconteceu o golpe político?! A partir de então, passamos a viver momentos muito difíceis em vários aspectos, inclusive com o corte e/ou redução das políticas

2 Entendendo que desde 2014, a elite brasileira não aceitou a reeleição da Presidenta Dilma Rousseff, minando a sua administração política e pública para em 2016 organizarem o seu impeachment, seguido de negociações entre os políticos da direita e fake news, nas mídias e redes sociais, para construir a demonização do PT - Partido dos Trabalhadores -; unindo a isso a impossibilidade de o Presidente Luis Lula da Silva concorrer as eleições de 2018, prendem-o sem crimes comprovados.

AMARAL, Maria das Vitórias Negreiros do. Arte/Educação e feminismo no imaginário 255 pernambucano como resistência política e formação identitária das mulheres.

Revista GEARTE, Porto Alegre, v. 6, n. 2, p. 247-271, maio/ago. 2019.

Disponível em: http://seer.ufrgs.br/gearte 


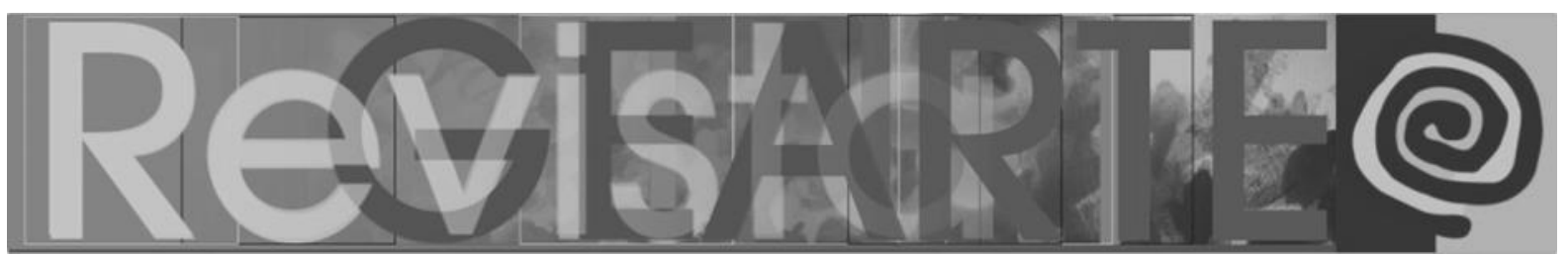

democráticas, que tinham como princípio direitos do cidadão e da cidadã; e isso se deu sobretudo com relação àquelas ligadas, direta ou indiretamente, aos governos Lula\&Dilma. Assistimos, muitas vezes passivamente, à caçada e à eliminação (execução, metaforicamente falando) de tais políticas que, ao mesmo tempo, são "substituídas", pelo menos no plano do discurso, por ações de extremo conservadorismo, a exemplo do fatídico pedido do Ministro da Educação às escolas, orientando que estudantes de escolas públicas cantassem o Hino Nacional e fossem filmados para enviar ao próprio Ministério. "Brasil acima de tudo. Deus acima de todos!" ecoa nos grupos adeptos a práticas antidemocráticas como essa, mas tal atitude ministerial foi considerada tão retrógrada que, felizmente, muitos secretários de educação, de boa parte do Brasil, se rebelaram e, por isso, escreveram cartas contrárias a essas arbitrariedades advindas da referida pasta; ao mesmo tempo, nas redes sociais pulularam vídeos em que eram denunciadas as precariedades das escolas públicas brasileiras.

É exatamente uma causa como essa que pode ser tomada pela relação arteeducação-sociedade-cidadania e, no nosso caso específico, pela mulher: ir contra atitudes de retrocesso que vão, aos poucos, prejudicando o povo brasileiro, em diversos campos, como na educação, na legislação trabalhista, nas leis previdenciárias etc. Afinal, o posicionamento precisa ser tomado, tendo em vista que essa onda direitista está ganhando força no mundo, e nós estamos vivendo momentos de indignação plena.

Dada a complexidade paradoxal constituinte do ser humano e dos desdobramentos de suas práticas e comportamentos na vida social, essa mesma indignação sofrida pelos abusos desmedidos do poderio direitista - em nível mundial - é a que alimenta a esperança de mudança, reforça a resistência e direciona à resiliência. Estamos diante de contradições, próprias do ser humano, que ficam mais evidentes quando se chega aos extremos e a uma polarização radical de posturas políticas. E é nessa "era de extremismos" que estamos vivendo agora. 


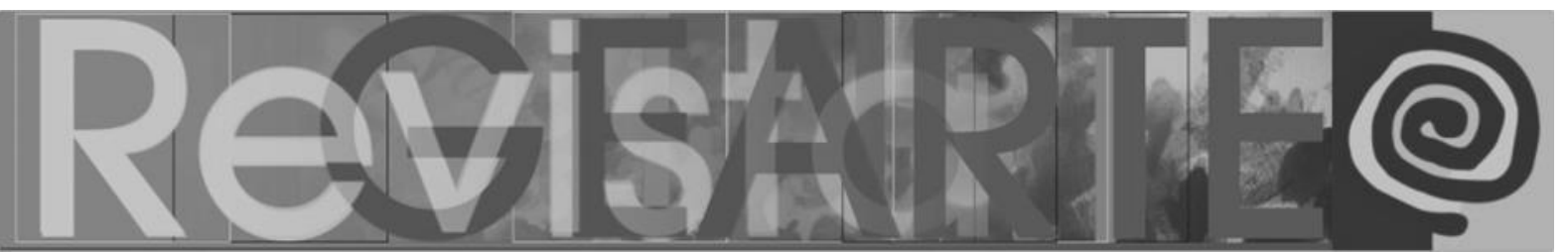

\section{Arte/Educação Ensino/Aprendizagem de resistência}

Diante do que foi exposto até o momento, perguntamos: qual é a relação do ensino/aprendizagem de arte com a atual configuração política e social que o Brasil vive hoje? O poderio econômico sob o controle da sociedade é uma política que deixa mais acirradas as relações de gênero, simplesmente porque ela é uma política de exclusão. Naturalmente, diante da força bruta - física ou simbólica -, e do aumento das milícias - formais e não formais, isto é, assumidas por pessoas comuns da própria população, inclusive que é incentivada a se armar -, as pessoas mais vulneráveis, como as mulheres, os pobres, os negros/as, os remanescente de quilombos, os indígenas, os grupos LGBT etc. são cada vez mais colocados à margem e, assim, calados. A esses grupos, portanto, a arte pode, dentro de sua atuação, e mesmo fora dela, materializar a emancipação dos sujeitos e, no limite, encaminhar processos particulares ou coletivos de resistência. Com efeito, defendemos que essas discussões estão na base do ensino/aprendizagem da arte, porque, sabemos, a arte reflete os momentos que vivemos - e isso, muitas vezes, causa incômodo. A arte na escola tem um papel fundamental, sobretudo porque propõe/trabalha com propostas que fazem que os/as estudantes pensem e se compreendam no mundo por meio da própria aprendizagem da arte.

Estamos tratando, como pode ser apreendido em nossa explanação/argumentação, de uma arte/educação inclusiva e de resistência, conforme já anunciado no próprio título deste trabalho. Como profissionais, temos que nos fazer cotidianamente uma pergunta, que não pode ser calada: como a arte das mulheres, dos/as indígenas, negros/negras e LGBT faz parte do nosso planejamento do ensino das artes visuais? Do mesmo modo: onde entra, nele, o estudo das produções das mulheres e dos demais grupos com relação ao imaginário que na arte produzida se constrói? Uma possibilidade para guiar nossas respostas às questões pode ser dada por Boas, que considera a importância do simbolismo nos estudos sobre a arte do seguinte modo: "(...) muito mais poderosa que as necessidades de 


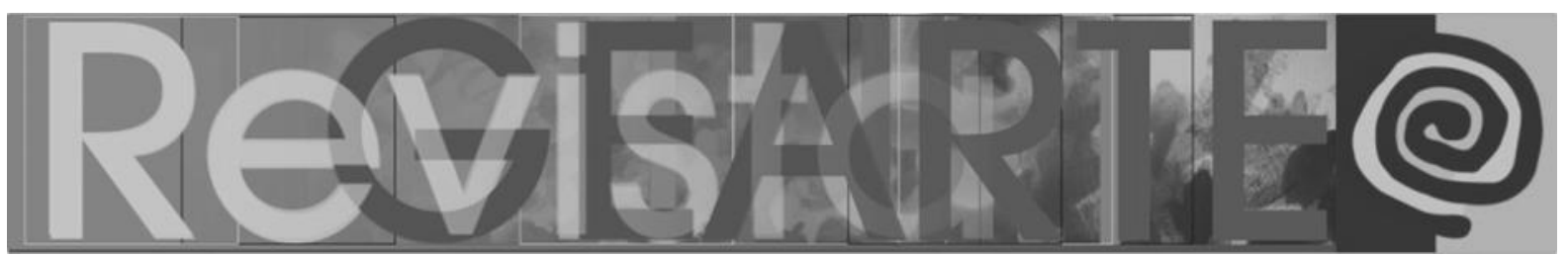

ajuste formal é a tendência simbólica que pode minimizar a representação reducionista de uma leitura superficial da forma" (BOAS, 1947, p.143).

Concomitantemente ao quadro contextual que descrevemos, acrescenta-se um dado contemporâneo: nossas relações perpassam o aspecto da superficialidade, promovida, por exemplo, pelas redes sociais, que, além disso, são os espaços onde mais se propagam imagens e notícias fakes e identidades construídas não com experiências, memórias e histórias, pois sintetizam imagens transformadas que fazem prevalecer o que o sujeito quer parecer ser. A verdade, que era única e absoluta, passa a ser múltipla; e as verdades se justificam pela fala do sujeito, de onde ele/ela está falando (suas escolhas teóricas e percursos históricos). Com isso, a ética fica ameaçada pelos políticos e pessoas, que estando mais preocupadas em aumentar o seu património pessoal, criam "verdades" com as fakes news, colocando em risco a segurança dos/as cidadãos/ãs e o sentido de sociedade democrática desaparece.

Para fugirmos dessa superficialidade, observamos a arte de grupos excluídos, como o das mulheres, e aprofundamos o estudo simbólico nas suas tradições, origens e desejos. Como já anunciamos, precisamos contar com um outro elemento importante, o cotidiano - que contextualiza a própria arte -, e compreendendo que, assim como a arte, ele, o cotidiano, é um plano privilegiado da expressão simbólica, considerando que todo símbolo só é significativo quando contextualizado.

Para Gilbert Durand (1997), o cotidiano é imprescindível para compreender o símbolo, porque ele surge a partir das tensões existentes, ao nível do imaginário, entre as pulsões subjetivas, assimiladoras e as imposições objetivas do meio cósmico e social. Sendo assim, para o antropólogo, o símbolo surge como produto no trajeto antropológico do cotidiano de cada grupo cultural. O meio material e social, que se deve instalar a pesquisa, é o que contextualiza o estudo sobre gênero na arte/educação, conforme estamos descrevendo.

Tratando da arte/educação, temos as valiosas contribuições da professora Ana Mae Barbosa, com a abordagem triangular, e da professora Marián Lopes Fernández- 


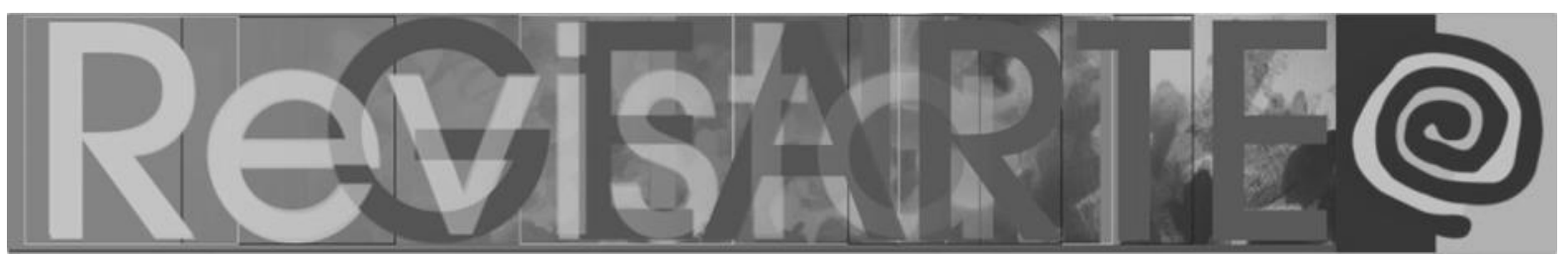

Cao, com seus estudos sobre a produção artística da mulher no ensino de arte e na recuperação dessa memória. Tais trabalhos nos possibilitam refletir sobre a compreensão das imagens expressas e originadas pelas/das mulheres ingressantes na graduação em Artes Visuais de nossa Universidade, bem como das mulheres artistas estudadas no curso e, além disso, como isso repercute na vida dessas mulheres fora do espaço acadêmico, considerando o seu cotidiano. A dialógica que permeia a pesquisa e a memória que faz vir à luz os nomes de artistas mulheres que são tão importantes para a nossa história, embora sejam tão pouco valorizados. Em outras palavras, em nosso trabalho como docente, fazemos reverberar a orientação prevista na defesa da importância dessa nova compreensão de arte, como explicita Fernández-Cao:

\begin{abstract}
Compreender como a ideologia de um momento ou de um lugar que impregnou os fundamentos da disciplina histórica é requisito fundamental para uma sociedade mais justa. Por isso a história da arte não deve ser a história da genialidade individual - ocidental, masculina e médio-burguesa -, e sim a história da criatividade por meio das imagens, transpondo individualidades, procedências geográficas e econômicas, onde a linha que separa arte e artesanato, desenho e arte, desapareça para mostrar novas maneiras de entender o mundo e de expressá-lo (FERNÁNDEZ-CAO, 2008, p.21).
\end{abstract}

Com efeito, temos como objetivo pensar uma Pedagogia em arte/educação e feminismo, mas por um viés pelo qual sejam estabelecidos novos diálogos sobre a produção artística da mulher, entre universidade, museus, escolas e a própria produção dos/as estudantes. Para tanto, faz-se necessário considerar que as imagens da arte são restauradoras da memória de uma produção artística esquecida e, por isso, venho ampliando esse olhar em sala de aula, nas orientações de pesquisa, de estágios, nos trabalhos de extensão, no PIBID, (Programa Institucional de Bolsa de Iniciação à Docência), programa federal que, em 2017, após o golpe, teve sua política alterada, o que fez com que vários professores/as - inclusive eu - se afastassem dele por não concordarem com as novas diretrizes então impostas; mas também em congressos, encontros e seminários dos quais participo: todos esses campos de atuação de "docente" e "pesquisadora" têm ajudado a ampliar as minhas pesquisas e visão feminista. 


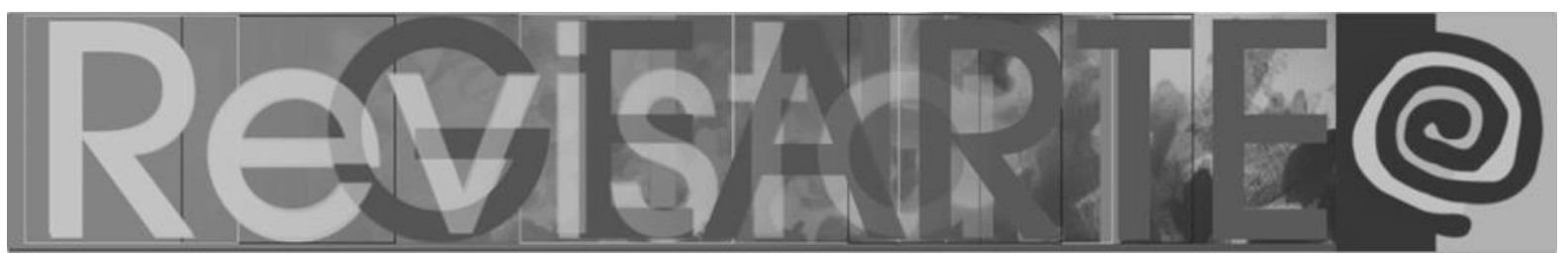

\section{Mudando com as pesquisas}

De acordo com Ana Mae Barbosa, "O Feminismo trouxe questões para a arte que permanecem vitais, sociais e estéticas até hoje, como por exemplo as definições de subjetividades, de agendas políticas pessoais e institucionais, de estratégias do corpo feminino e múltiplas narrativas, da relação entre público e privado, e da relação entre arte e artesanato" (BARBOSA in ZACCARA, 2017, p.13).

Talvez alguns locais tenham conseguido mais transformações nas relações de gênero, mas na cultura brasileira isso ainda não ocorreu. Quando as mulheres começam a aparecer nas mídias devido a algum papel importante que assumem ou em posições de destaque, inicia-se uma guerra de poderes na tentativa de invisibilizálas, ou de apresentá-las como loucas, putas ou incapazes de realizar um bom trabalho, ou seja, constrói-se uma corrente de argumentos que visa a desqualificar a mulher e, consequentemente, o seu trabalho. Madalena Zaccara discute esse tipo de comportamento, afirmando que "(...) durante séculos as mulheres foram prisioneiras do biológico. Não podiam ocupar os espaços de poder no mundo público porque não eram aptas às tarefas complexas. Incapazes, logo inferiores. A insignificância de suas vozes e ações era consequência da pouca valia dos seus corpos e dos cérebros, o que culturalmente Ihes era atribuído, bem como a tutela masculina que Ihes cerceava as portas da educação, do conhecimento, o que resultou em exclusão profissional (ZACCARA, 2017, p.22).

As mulheres, como protagonistas de histórias, são omitidas; e no caso brasileiro temos muitos exemplos a retomar. Podemos dizer que nessas histórias de omissão há uma morte, uma morte que ronda as mulheres, seja no apagamento das histórias que elas construíram e que por isso deveriam estar presentes nos livros, mas não estão; ou pelas mortes que ocorrem de fato. De um modo ou de outro, a morte existe, seja simbólica ou real.

Mesmo com todas as iniciativas que até pouco tempo lançavam um olhar diferenciado para, por exemplo, a violência doméstica; o feminicídio tem aumentado 


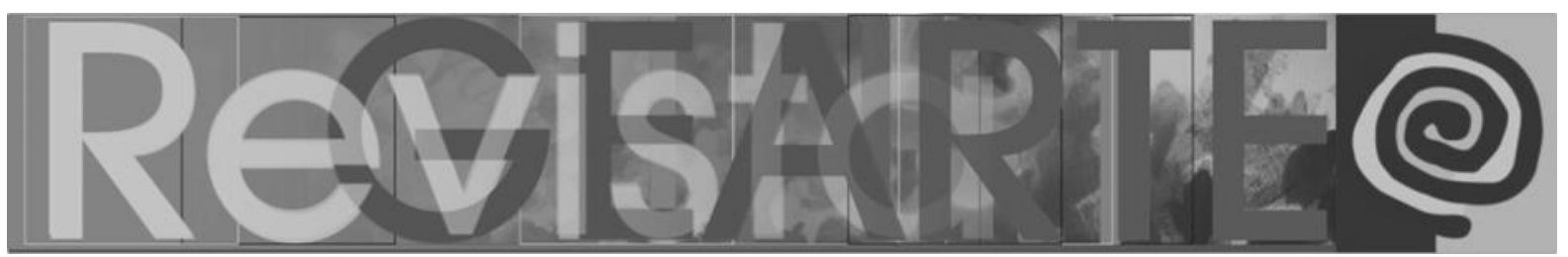

e tornou corriqueiro em nosso país mulheres serem mortas por seus parceiros: apenas em janeiro de 2019, 119 mulheres foram mortas, mais de 200 em março, pelo simples fato de serem mulheres ${ }^{3}$. Tanto a omissão como o desaparecimento das mulheres são um fato, que, como dissemos, podem ser interpretados literalmente ou não como morte, e na arte ocorre este mesmo tipo de processo: as mulheres existem, fazem arte e não são reconhecidas; são, ainda, como no caso de Camile Claudel, consideradas loucas, ou têm mortes misteriosas como a de Ana Mendieta. É inegável a importância dessas mulheres para os estudos da arte. Mas me deterei ao exemplo de Ana Mendieta (1948-1985) sobretudo pelo trabalho performático de qualidade que realizou. Cubana, radicou-se nos Estados Unidos, onde morou com o esposo Carl Andre, também artista. A morte dela é envolta por um grande e "insolúvel" mistério: Ana despencou de seu apartamento em Nova lorque, e seu marido, embora acusado de assassinato, foi absolvido por "dúvida razoável", e o caso até hoje não foi devidamente esclarecido.

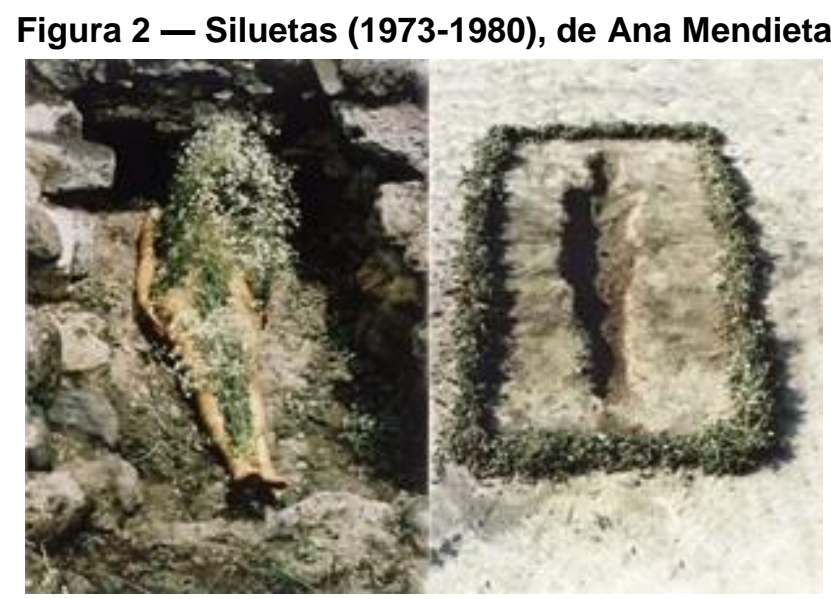

Fonte: Ana Mendieta: Earth Body, Sculpture and Performance 1972-1985, organized by Hirshhorn Museum and Sculpture Garden, Smithsonian Institution, Washington DC. 2004.

Mendieta apresentava como foco de seu trabalho artístico as conexões entre o físico e o espiritual com a Terra. Durante sua vida, produziu mais de duzentas obras usando a terra como uma espécie de "médium natural". Na série Siluetas (1973-1980), por exemplo, a artista cria silhuetas femininas na natureza e, para tanto, utiliza como

3 Disponível em http://meteacolher.org.

AMARAL, Maria das Vitórias Negreiros do. Arte/Educação e feminismo no imaginário 261 pernambucano como resistência política e formação identitária das mulheres. Revista GEARTE, Porto Alegre, v. 6, n. 2, p. 247-271, maio/ago. 2019.

Disponível em: http://seer.ufrgs.br/gearte 


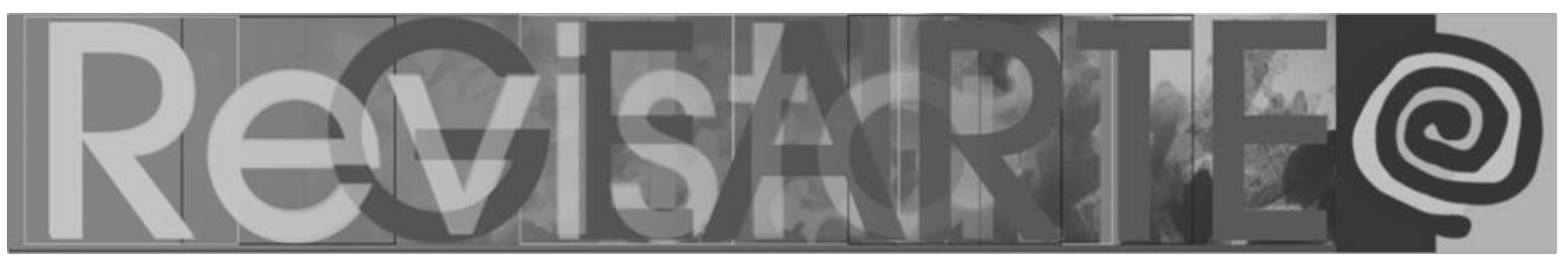

matéria a lama, a areia e a grama em conjunto com materiais naturais extraídos de folhas, galhos e sangue, fazendo impressões com o corpo ao expor a sua silhueta em uma parede; seu corpo torna-se um canal por meio do qual a própria terra grita, bem como a natureza e a mulher ganham um local privilegiado para fazer ecoar seus discursos ${ }^{4}$.

A morte de Mendieta foi uma das poucas que foram mostradas na mídia, ganhando uma certa repercussão, mas não o suficiente para ser feita a justiça mesmo ela sendo bem conhecida. Apesar da divulgação midiática, ela só teve reconhecimento internacional depois de algum tempo. Mas, e quanto às mulheres/artistas (ou não) que morreram e não tomamos conhecimento? $\mathrm{E}$ as que parecem ter morrido de morte natural? E isso não acontece apenas no mundo da mulher artista, mas na vida de muitas mulheres. $E$ as mulheres que morrem em vida? Em pesquisa de mestrado em Artes Visuais (UFPE/UFPB), Anna Carolina Cosentino ${ }^{5}$ investigou mulheres de sua família que morreram em vida por perderem seus filhos ou filhas para os pais. Para a pesquisadora:

No caso familiar que relato, a morte não significou o fim das tribulações, visto que bastava uma nova tentativa de recomeço e as mesmas adversidades se estabeleciam. Poderiam as repetições acima citadas estarem relacionadas a uma ideia de preservação da vida, como se fossem "um grupo de hábitos orgânicos" passados geracionalmente adiante? Ou as mesmas referem-se a uma intensificação excessiva do amor das mães por suas crias, que não se efetua no entanto, levando à morte? O que poderia estar por trás da repetição dessa descontinuidade afetiva? (COSENTINO, 2018, p.22).

Não acontece isso apenas no mundo da arte, mas nas outras esferas de nosso cotidiano também. Assim, meninas, mulheres, amantes são mortas, por seus familiares, mortas por seus companheiros, amantes, namorados etc. No Brasil, em 2018, o índice de homicídios de mulheres foi de 4.254, o que apontou um crescimento

4 COURI, Aline. consultado em 16/02/2016: https:/topicoespecialvideoarte.wordpress.com/2016/02/17/ofeminismo-em-ana-mendieta).

5 COSENTINO, Anna Carolina Coelho. Fantasmas Corpocosa. Refazendo significados afetivos por meio da performance. Dissertação defendida no Programa Associado de Pós-Graduação em Artes Visuais (PGAV-UFPE/UFPB, em 2018.

AMARAL, Maria das Vitórias Negreiros do. Arte/Educação e feminismo no imaginário 


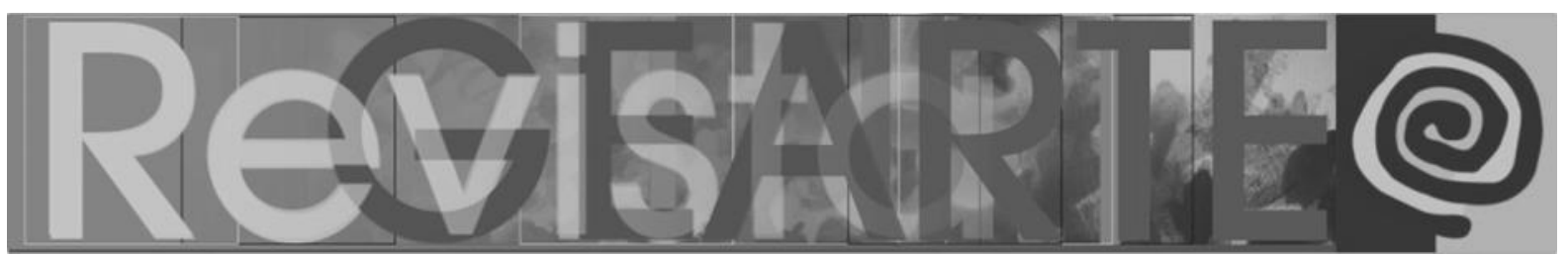

de feminicídios em relação ao ano anterior. Isso porque temos uma sociedade regida por mitos recorrentes que reforçam a narrativa mítica judaico-cristã de Adão e Eva, uma Eva que carrega a culpa de todos os pecados do mundo. Pecados? E o que são pecados? Só quem os comete são as mulheres? Na nossa sociedade, se as mulheres forem abusadas, estupradas, xingadas, enfim, violentadas física, moral ou simbolicamente, "a culpa será sempre das mulheres", que, por sua vez, ainda têm que ouvir perguntas do tipo: "Você deu bola?"; "Estava com roupa curta?"; "Provocou?"; "Anda nua, por isso foi estuprada!", "Conhece no primeiro dia e leva pra casa", ou seja, qualquer coisa é justificativa para a violência contra as mulheres. Violência essa que acontece dentro de casa, conforme um estudo realizado pela Comissão de Defesa dos Direitos da Mulher da Câmara dos Deputados e pela a Associação de Educação do Homem de Amanhã de Brasilia (HABRA): “(...) 96,8\% dos casos de estupro de menores de 14 anos foram causados por abusadores que compartilham laços sanguíneos ou de confiança com a família. Apenas 3,2\% são desconhecidos" (LADO B / Edição no 19 \#8M: "O protagonismo feminino veio pra ficar" - Revista Fórum de 8/3/2019). A violência e a discriminação, conforme já amplamente comprovado pela literatura especializada, começam no seio da própria família.

Estamos numa sociedade na qual as mulheres são objetos de uso, humilhação e, por isso, recebem maus tratos e são mortas. Aos homens: pais, maridos, namorados, conhecidos e estranhos, mas também a colegas, patrões etc., temos que dar um basta! E um dos caminhos para que isso ocorra de fato passa também pelas sendas da educação, a exemplo do trabalho de Thaysa Cordeiro Silva, estudante/artista/pesquisadora e bolsista do PIBIC (UFPE), que desenvolve a pesquisa "Estudos sobre o panorama de violência contra a mulher no Recife e práticas de arte/educação como resistência", que tem, como proposta:

O panorama de violência contra a mulher no Recife é explicitamente reconhecido pelas mídias e pesquisas públicas como um dos maiores do Brasil. Na tentativa de nos incluirmos nessa discussão que já acontece em várias áreas de conhecimento da academia, pretendemos introduzir essa discussão no campo do ensino de Arte. Neste projeto, pretendemos relacionar os índices de violência e feminicídio no estado de Pernambuco, especificamente no Recife, às leituras sobre gênero e arte/educação, na 


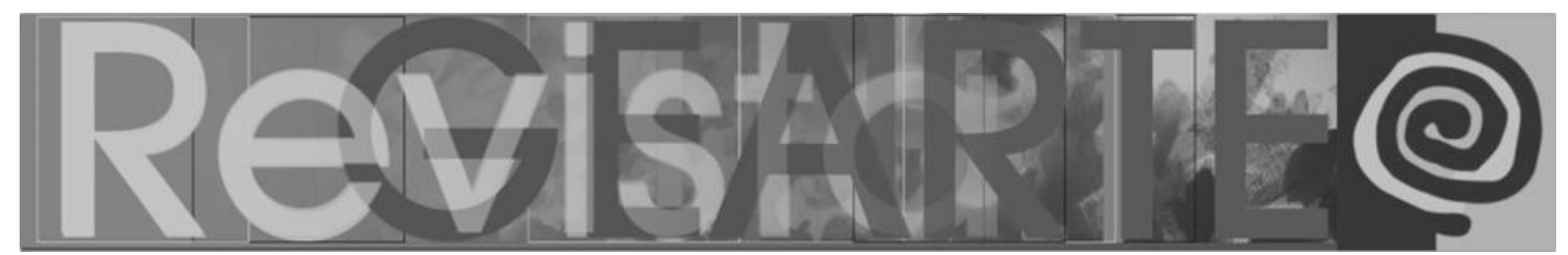

tentativa de elaborar uma pedagogia capaz de emancipar a sociedade, transformando a sua visão reprodutivista patriarcal existente na sala de aula e nos campos não-formais. As práticas de arte/educação têm uma força que é evidente nas ações artísticas que trazem imagens vivenciadas pelos sujeitos sociais e fazem com que eles/as tenham consciência dessas imagens e a partir delas haja uma transformação pessoal e coletiva (SILVA, projeto do PIBIC 2018/2019).

As estatísticas encontradas pela estudante/artista/pesquisadora apontam para dados assustadores de feminicídio, homicídio por motivo de gênero, violência doméstica e familiar e, além disso, os próprios meios de comunicação exploram comercialmente todo tipo de violência, inclusive a moral, embora sejam apagadas das mídias e mesmo das pesquisas tantas outras formas de violência que são silenciadas.

Figura 3 - Performance Matadouro ${ }^{6}$

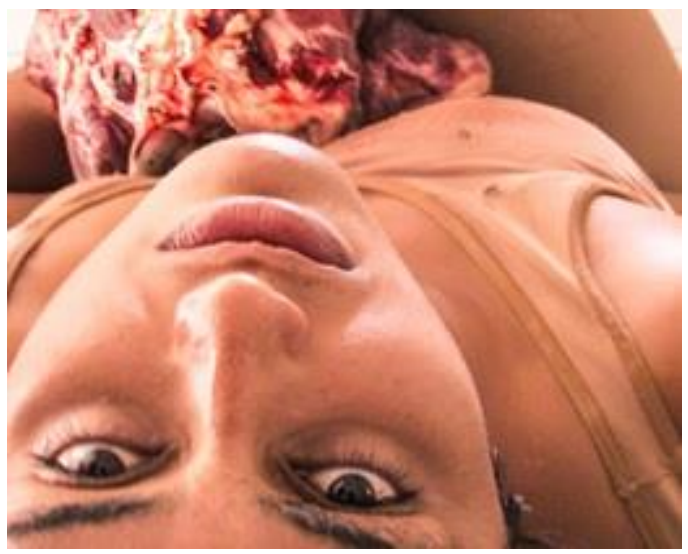

Fonte: foto de Leandro Roberto, edição de imagem Chico Ludermir e Victor Hugo Borges.
Figura 4 - Mediação na Galeira Corbiniano Lins ${ }^{7}$

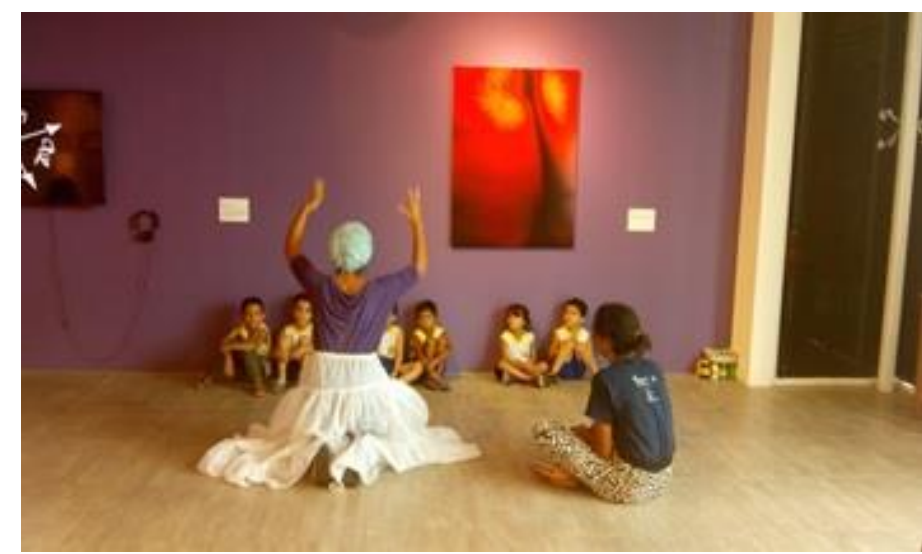

Fonte: foto de Abiniel João Nascimento.

Atualmente, a estudante Thaysa estagia na Galeria Corbiniano Lins, no SESC$P E$, e leva suas narrativas feministas para as mediações. Ela é uma estudante bem atuante e participa de vários encontros, fez teatro na Escola Municipal de Arte João

6 Este é um dos trabalhos premiados no IX Salão Universitário (Único) de Arte Contemporânea, exposto na Galeria de Arte do SESC Casa Amarela (Recife) e Galeria Ana das Carrancas SESC Petrolina (SILVA, Thaysa, 2017).

7 Mediação com contação de história para crianças da escola pública Emídio Dantas, durante o $\mathrm{X}$ Salão Universitário (Unico) de Arte Contemporânea, na Galeria de Arte Corbiniano Lins no SESC Santo Amaro, Recife - PE. (SILVA, Thaysa, 2018) Atividade realizada juntamente à mediadora (mulher trans) Núbia de Aquino e o artista da obra mediada Abiniel João Nascimento. 




Pernambuco (EMAJP) , concluindo o nível básico, e participou do Porta Aberta dessa escola, em 2017 apresentando a performance "Tempos Vermelhos", evento ocorre que todo final de semestre, período em que os/as estudantes fazem a mostra dos trabalhos realizados durante os semestres. No evento "O protagonismo da mulher nas artes" Thaysa organizou, fez mediação de uma das mesas e deu uma oficina intitulada "Inter_ditada", na qual propõe rodas de conversa e uma prática performática.

Figuras 5 e 6 - Atuação e grupo de trabalho da estudante Thaysa Cordeiro
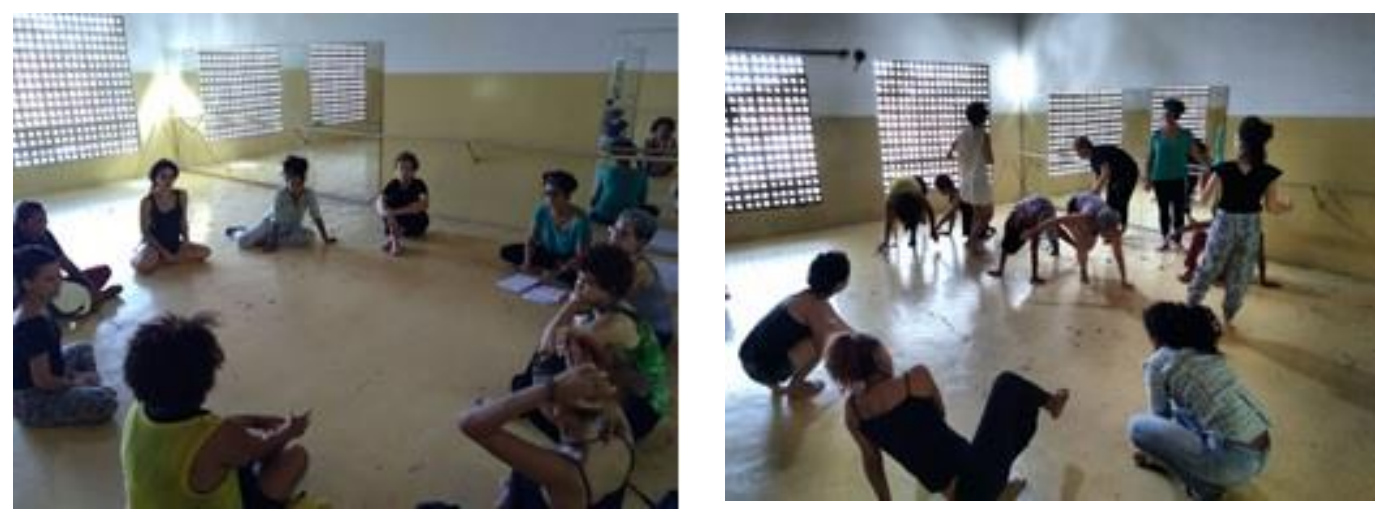

Fonte: Fotos de Eli Yon.

Além dessas atividades de Thaysa, apresento mais duas estudantes/artistas/pesquisadoras: Alana Torquato Araújo e Stefany Lopes de Lima, ambas também bolsistas do PIBIC (UFPE). No conjunto, são três pesquisas que nasceram da vontade de pensar esse lugar, que eu, como disse, considero feminista. Thaysa, Alana e Stefany buscam responder as suas inquietações de mulheres, e as nossas como mulheres pesquisadoras também. 


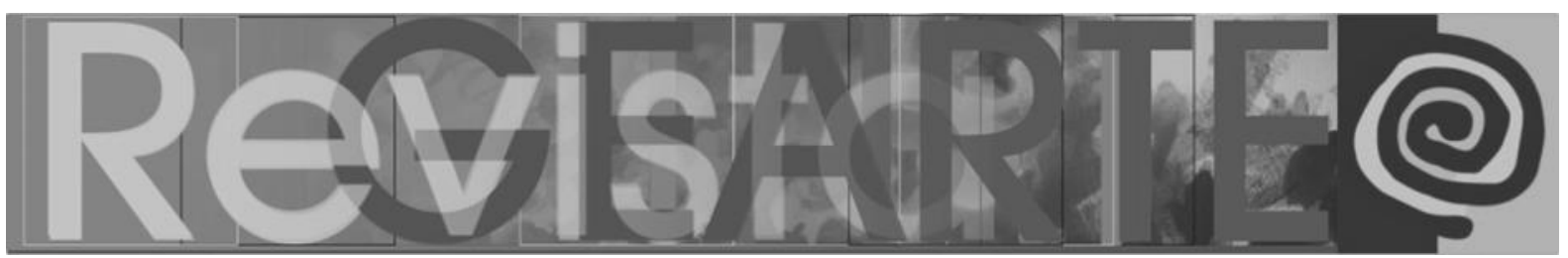

Figura 7 - Produção em acrílico com colagem

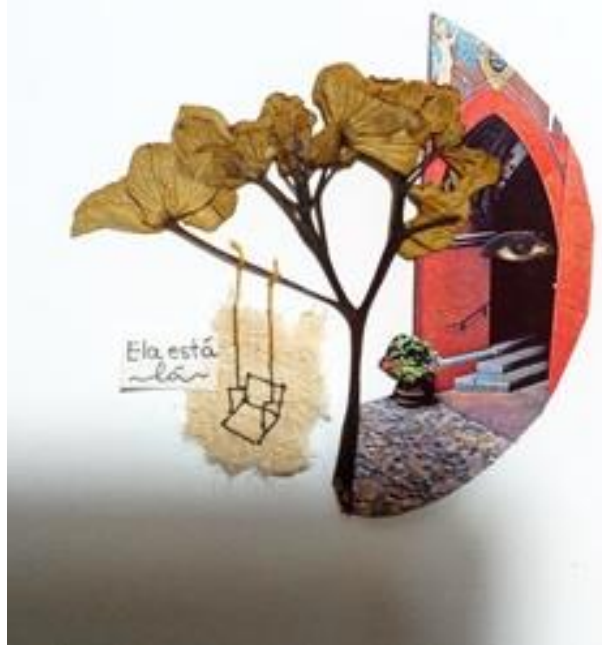

Fonte: Produção e foto de Alana Araújo.

"Por que o curso não fala de mim?", pergunta-se Alana, que ainda vai além: "como a criatividade é tratada no curso de Artes Visuais, no qual os/as estudantes que o iniciam têm tão pouco conhecimento/produção de arte ou quase nenhuma?". Seu desejo é pensar o currículo do curso Licenciatura em Artes Visuais da UFPE, e como o feminino e o pensamento feminista afetam os processos criativos dos/as estudantes, refletindo a sua relação com a produção artística - aliás, foi essa inquietação que a levou para a produção da pesquisa.

Continuando com uma mesma epistemologia do ensino/aprendizagem da arte numa perspectiva feminista, Stefany trabalha no sentido de devolver à rua a juventude da periferia, invertendo a ideia de "tirar os jovens da rua". Para tanto, ela utiliza o graffiti para ocupar o espaço da rua, desconstruindo a imagem de que a rua é um ambiente hostil, agravante da violência e da marginalização à qual os/as jovens de periferia estão suscetíveis. Na verdade, sabemos, esse fator só pode ser compreendido a partir de uma análise dos paradigmas simbólicos, além dos impactos do racismo e das dimensões da desigualdade social. Muitas das violências ocorridas contra as mulheres acontecem dentro de casa com seus parceiros, pais e parentes próximos, de acordo com o que já sinalizamos, e conforme os dados obtidos pelo trabalho de Stefany:

Através da vivência nesses espaços, pude ampliar meu olhar e meu repertório artístico-cultural, refletindo com maior profundidade sobre minhas origens, minha identidade e meu corpo no mundo. A pesquisa parte da premissa de compreender o impacto artístico, educativo e social para os jovens frequentadores desses espaços, em relação ao processo de ensino/aprendizagem nas oficinas de graffiti e como ele reverbera em suas respectivas comunidades (LIMA, Stefany, relatório de pesquisa: 


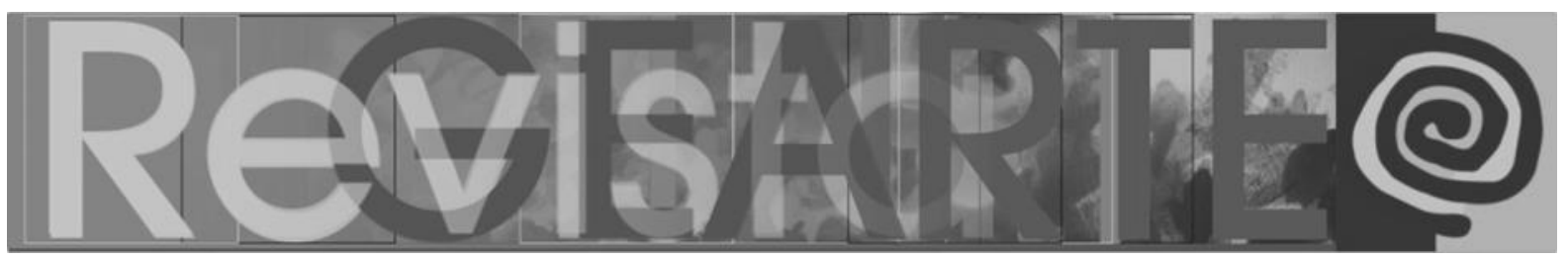

Arte/Educação e graffiti em espaços não formais: devolvendo a rua à juventude periférica, 2018).

As três pesquisas utilizadas como exemplo foram aprovadas pela Universidade, e suas realizadoras recebem uma bolsa de pesquisa do CNPq; mesmo que tímida, eu considero louvável essa mudança nos critérios de pesquisa, com uma tendência a uma epistemologia decolonial, considerando aspectos que outrora eram percebidos como irrelevantes para a Ciência. Afinal, pesquisas que ressaltam a "criatividade" ou o "graffiti como arte", em bairros periféricos, ou sobre a violência à mulher, são olhares feministas sobre a sociedade e começam a ter espaço também como ciência. Essas são mudanças que surgem como um rompimento de paradigmas, a partir do qual começamos a compreender a pesquisa horizontalmente, de forma com-partilhada e pensada na melhoria de vida das pessoas, além da democratização do conhecimento, como, no nosso caso, do conhecimento das Artes Visuais.

Enquanto nas salas de aulas de história da arte ainda adotamos os historiadores que tratam apenas de histórias de homens, brancos e europeus ou estadunidenses, os quais apresentam artistas homens em suas histórias; as mulheres fazem arte em seus ateliês privados ou públicos, em casa ou em qualquer outro lugar. Mulheres que jamais entrarão nos livros de arte, se eles não forem escritos por mulheres, divulgados por mulheres, refletidos por mulheres.

Essas artistas afetam realmente as estudantes e as empoderam, levando-as a produzirem seus próprios trabalhos de arte; são representações para jovens de periferia e já iniciaram uma história em suas comunidades, a ponto de sentirem que podem continuar com a sua história e dar visibilidade a sua arte, como Stefany, por exemplo, que interage com as artistas conhecidas a partir da universidade. Esse tipo de relação promove indubitavelmente uma troca constante nos saberes e fazeres da arte. 


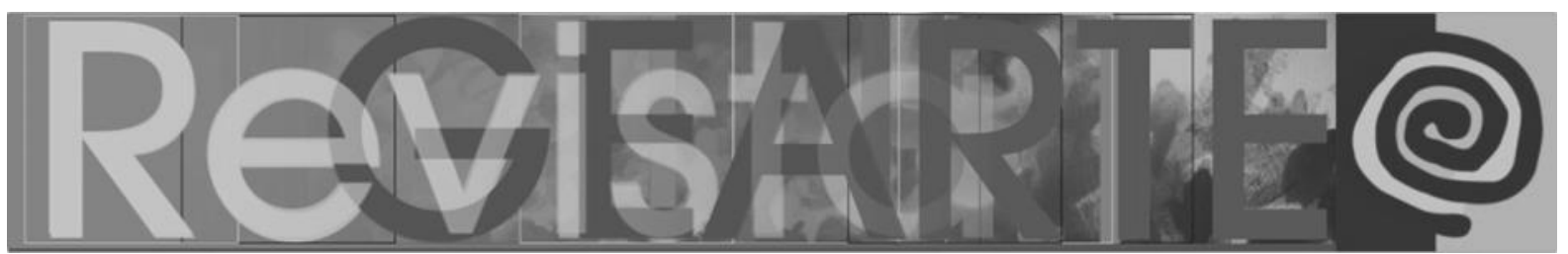

Figura 8 - Perfomarmances-obras ${ }^{8}$ de Christina Machado

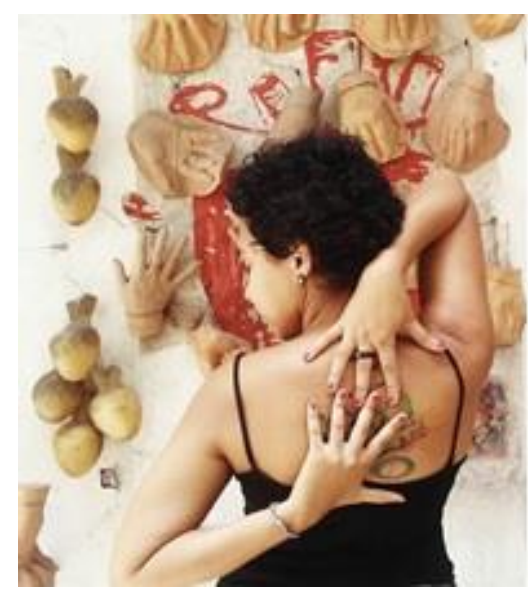

Fonte: foto @carol.aleh
Figura 9 - Stefany grafitando

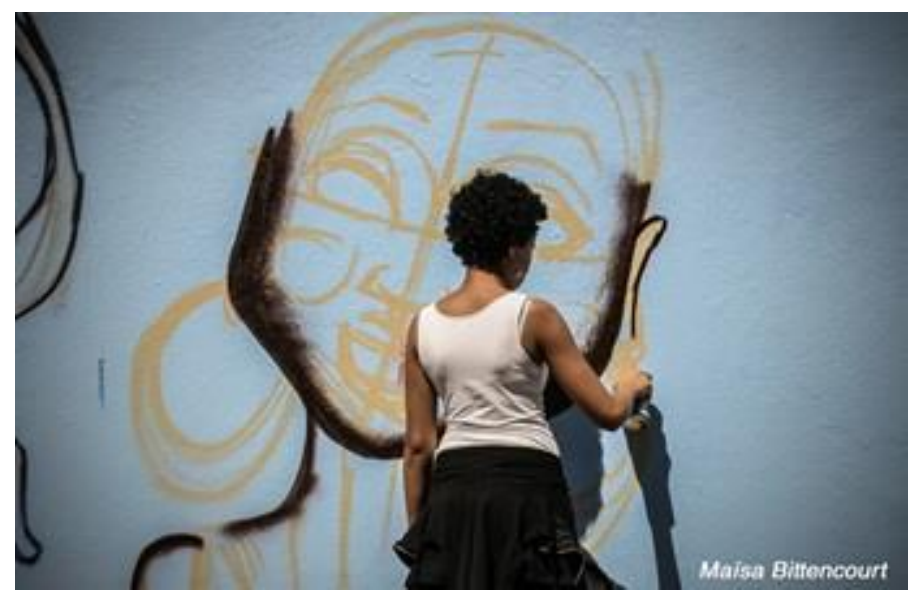

Fonte: foto de Maísa Bittencourt

Stefany Lopes de Lima, a quem já nos referimos, é estudante/artista/pesquisadora, grafiteira e tem assumido aulas de artes, como estagiária, na Escola Municipal de Arte João Pernambuco. Nessa escola, ela tem experimentado discutir sobre os/as artistas que estão fora do circuito hegemônico, ressaltando no trabalho dele/as o discurso feminista e o da valorização da negritude.

Abaixo são apresentados alguns trabalhos produzidos por seus estudantes, que foram expostos na escola no final de 2018:

8 Trabalho de parto, dor e prazer (in)tenso do (re)nascer corpo, carne, cheiro, percorrer as linguagens, entre os dentes, as poéticas do-eu. 


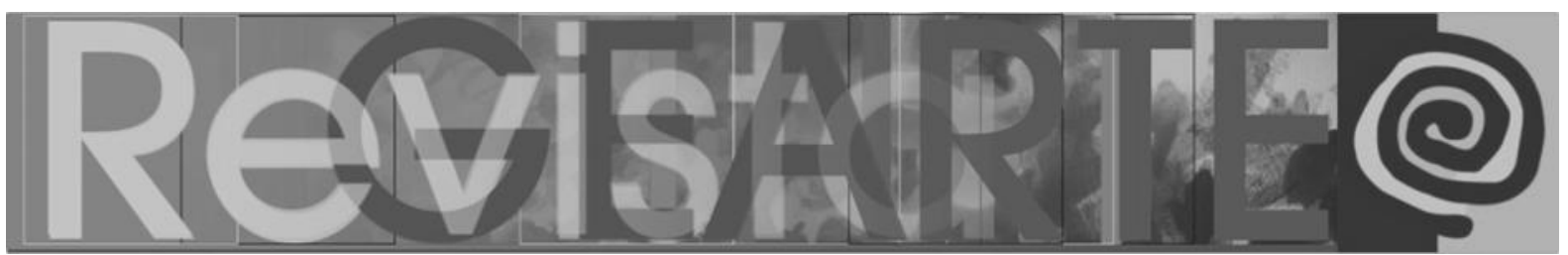

Figuras 10 e 11 - Trabalhos de alunos/as da Escola Municipal de Arte João Pernambuco
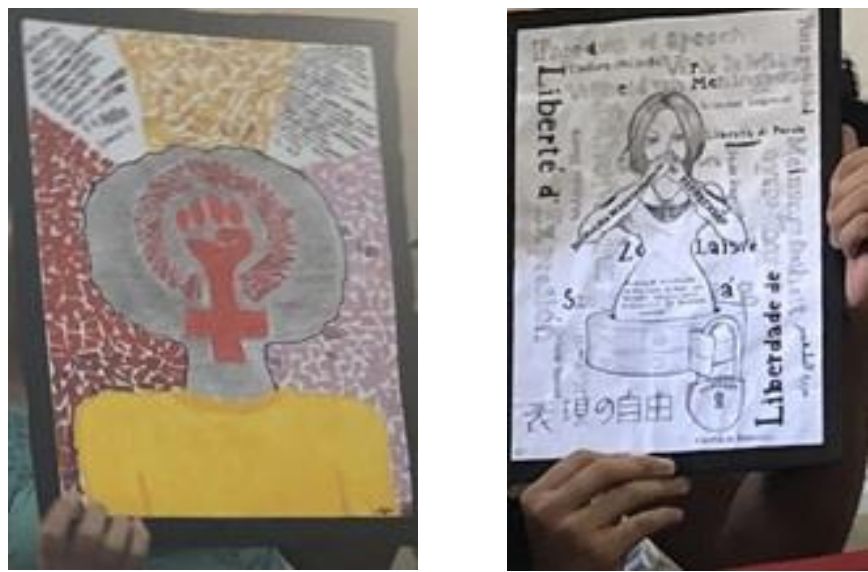

Fonte: arquivo da autora.

E, por fim, apresento uma ação que Thaysa, Stefany e mais algumas colegas do curso fizeram juntas nas ruas do Recife. A primeira, Arte para lambe-lambe, foi criada para a mobilização do 8 de março de 2019, com o intuito de tratar do autocuidado relacionado à questão da violência de gênero. A segunda ação foi a produção de um lambe-lambe que foi colado na Ponte do Derby, também durante a mobilização do 8 de março. Nele, encontram-se informações de características vivenciadas por mulheres em relacionamentos abusivos, com o intuito de ajudá-las a identificar os primeiros sinais de violência em seus relacionamentos.

Figuras 12 e 13 - Lambe-lambes produzidos por Thaysa Silva, expostos nas ruas da cidade do Recife, no dia 8 de março de 2019, pela autora e um grupo de colegas do curso de Artes

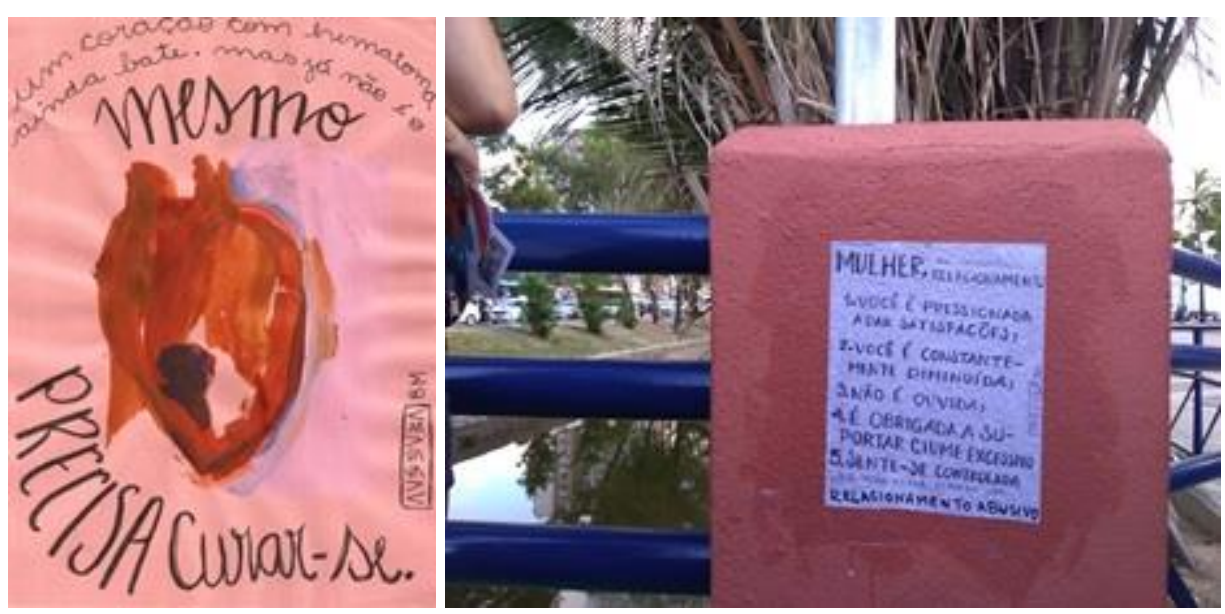

Fonte: Fotos de Rayellen Alves. 


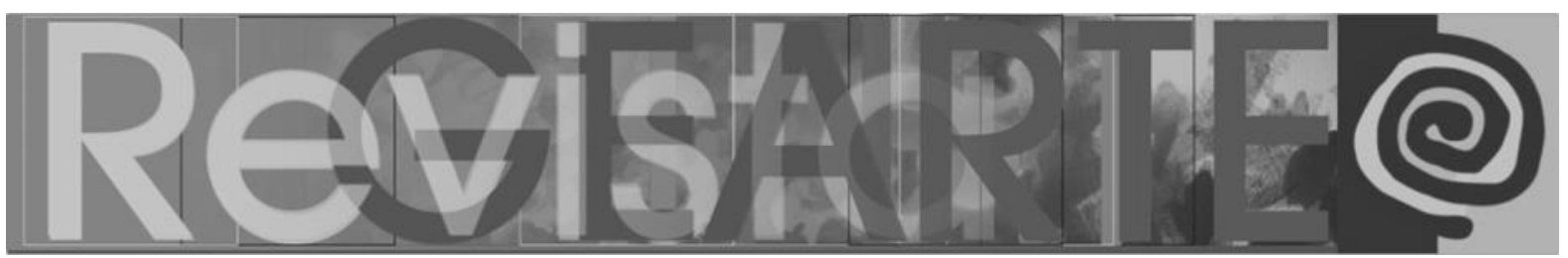

Ambos os trabalhos foram embasados pela pesquisa PIBIC "Estudos sobre panorama de violência contra a mulher no Recife e práticas de arte/educação como resistência", de Thaysa Cordeiro, mas que foi realizada por várias mulheres, colegas do curso.

Os trabalhos aqui apresentados mostram a reverberação dos percursos históricos, artísticos e feministas de ser e lutar por todas, de gritar por todas. Assim, é evidente a importância de uma ação pedagógica orientada para um fim, que pode explorar não apenas as potencialidades humanas, mas também ganhar um público que se identifica com a causa e reflete sobre ela em espaços que, num primeiro momento, não são comuns para promover tais reflexões. Nesse ciclo ruauniversidade-rua, observamos o quanto as influências das estudantes nos afetam e como nós afetamos a estudantes. A discussão ainda está no início, apesar de todas as lutas, e neste momento em particular é importantíssimo que não nos calemos.

A arte/educação já está sendo apresentada de modo a envolver em seus temas o feminismo, e isso já se mostra também como resistência política (dentro da universidade e fora dela) e, claro, como a formação identitária das mulheres; então, com a realização deste trabalho para este congresso, ganha ainda mais força, no sentido de juntar mais pessoas para discutir, refletir e refletir, conseguindo com isso poder aliar a trabalhos de outras esferas, inclusive de movimentos sociais, como o movimento feminista mesmo, e de fato projetar no imaginário pernambucano de agora essas ações transversais/horizontais, mas não apenas no agora, mas projetadas também para o futuro, para as futuras gerações, e aí esse mesmo imaginário transformado, um dia, a sociedade não se surpreenda mais com temas como os apontados aqui e que eles façam parte da Educação como um todo.

Avante! 


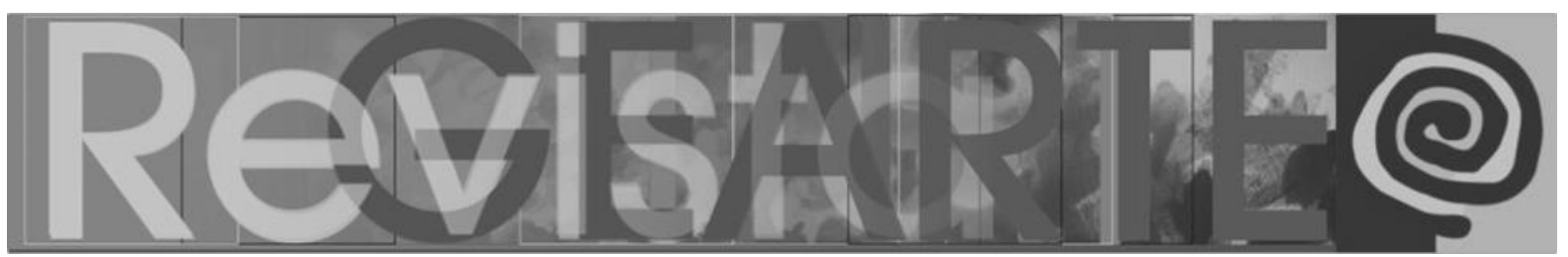

\section{Referências}

ADICHIE, Chimamanda Ngozi. Sejamos todos feministas. Tradução de Christina Baus. São Paulo: Companhia das Letras, 2015.

BARBOSA, Ana Mae. Arte no Brasil: várias minorias. Tradução de Cyana Leahy. In: FARRISDUFRENE, Phoebe (Eds.). Voices of color: art and society in the Americas. London: Humanities Press International Inc., 1997.

BOAS, Franz. El arte primitivo. Buenos Aires: Fondo de Cultura Económica, México, 1947.

BLOG FÓRMULA GEO. Disponível em: <http://formulageo.blogspot.com.br/2012/07/mafalda -encimae-embaixo-no-mapas>. Acesso em: 06 jun. 2014.

CAO, Márian López Férnandez. Educar o olhar, conspirar pelo poder: gênero e criação artística. In: BARBOSA, Ana Mae; AMARAL, Lilian. (Orgs.) Interterritorialidade: mídias, contextos e educação. São Paulo: Editora Senac/ São Paulo: Edições SESC SP, 2008.

DURAND, Gilbert. As estruturas antropológicas do imaginário: introdução à arquetipologia geral. Tradução de Hélder Godinho. São Paulo: Martins Fontes, 1997.

LADO B / Edição no 19 \#8M: "O protagonismo feminino veio pra ficar". Revista Fórum de 8/3/2019.

LARRALDE, Gabriela. Diversidad y género en la escuela. Ciudad Autónoma de Buenos Aires: Paidós, 2018.

MIGNOLO, Walter. La colonialidad: la cara oculta de la modernidad. Disponível em: http://www.macba.es/PDFs/walter_mignolo_modernologies_cas.pdf. Acesso em: 16 jun. 2018.

MIGNOLO, Walter. Desobediencia epistémica: retórica de la modernidad, lógica de la colonialidad y gramática de la descolonialidad. Buenos Aires: Ediciones del Signo. 2010.

RAGO, Margareth. Feminismo e subjetividade em tempos pós-modernos, 2004. Disponível em: http://www.historiacultural.mpbnet.com.br/feminismo/Feminismo_e_subjetividade.pdf. Acesso em: 16 jun. 2018.

ZACCARA, Madalena (Org.). De sinhá prendada à artista visual: os caminhos da mulher artista em Pernambuco. Recife: Ed. do Organizador, 2017.

\section{Maria das Vitórias Negreiros do Amaral}

Professora de Artes Visuais da Graduação e Pós-Graduação em Artes Visuais (PPGAV) da Universidade Federal de Pernambuco; atualmente é a coordenadora do PPGAV-UFPE; é Pós-doutora em Feminismo e Arte/Educação pela Universidad Complutense de Madrid; Doutora em Artes/VisuaisArte/Educação pela USP; Mestra em Antropologia pela UFPE.

E-mail: vitorianegreirosamaral@gmail.com

ORCID: https://orcid.org/0000-0002-7923-1906

Currículo: http://lattes.cnpq.br/3317479462307817

Recebido em 1 de abril de 2019

Aceito em 18 de maio de 2019 